\title{
KONSEP KOSMOLOGI CANDI GEDONG I MUARA JAMBI SEBAGAI SUMBER PEMBELAJARAN SEJARAH DI SMA AZHARYAH PALEMBANG
}

\author{
Oleh: Desi Efrili Yani*, Sukardi** \\ *Mahasiswa Program Studi Pendidikan Sejarah Universitas PGRI Palembang \\ ${ }^{* *}$ Dosen Program Studi Pendidikan Sejarah Universitas PGRI Palembang
}

\begin{abstract}
ABSTRAK
Candi Gedong I Muara Jambi yang kaya akan peninggalannya memiliki nilai sejarah yang tinggi makna konsep kosmologi pada tata letak candinya. Belum semua data sejarah tersebut dapat dimanfaatkan dalam pembelajaran sejarah. Permasalahan dalam penelitian ini adalah nilai sejarah apakah yang terdapat pada konsep kosmologi candi Gedong I Muara Jambi yang dapat dimanfaatkan sebagai sumber pembelajaran sejarah?. Tujuan penelitian mengetahui nilai sejarah apakah yang terdapat pada konsep kosmologi candi Gedong I Muara Jambi yang dapat dimanfaatkan sebagai sumber pembelajaran sejarah. Metode yang digunakan dalam penelitian ini adalah deskriptif kualitatif dengan menggunakan cara pengumpulan sumber-sumber secara sistematis dan menggunakan sumber data secara mendalam. Berusaha memahami dan menafsirkan makna suatu peristiwa interaksi tingkah laku manusia dalam situasi tertentu menurut perspektif peneliti sendiri. Teknik pengumpulan data melalui observasi, wawancara dan dokumentasi. Hasil penelitian: makna nilai sejarah konsep kosmologi candi Gedong I digambarkan dalam bentuk arsitektur candi yang merupakan replika dari jagad raya. Bangunan candi diumpamakan sebagai gunung Meru, pagar keliling candi Gedong I diumpamakan sebagai rangkaian pegununga yang mengelilingi pusat jagad raya dan parit atau kanal yang mengelilingi candi Gedong I diumpamakan sebagai samudera.
\end{abstract}

Kata Kunci: Konsep Kosmologi, Candi Gedong I, Sumber Pembelajaran Sejarah

\section{A. PENDAHULUAN}

Kota Jambi menjadi daerah otonom di provinsi Sumatera Tengah berdasarkan UU Nomor 9/1956. Satu tahun kemudian provinsi ini dihapus berdasarkan UU darurat RI Nomor 19/1957 dan dimekarkan menjadi tiga provinsi yaitu Jambi, Riau dan Sumbar. Lalu UU Nomor 61/1958 mengukuhkan UU darurat tersebut. Dan sejak tahun 1957 pusat pemerintahan provinsi Jambi berada di kota Jambi (Dhakidae, 2003: 150).

Secara geografis, provinsi Jambi terletak antara $0^{\circ} 45^{1}$ Lintang Utara, $2^{\circ} 45^{1}$ Lintang Selatan, dan $101^{\circ} 0^{1}$ - $104^{\circ} 55^{1}$ Bujur Timur. Luas keseluruhan wilayah provinsi Jambi adalah $53.435,72 \mathrm{Km}^{2}$ dengan luas daratan sebesar $51.000 \mathrm{~km}^{2}$, lautan 425,5 $\mathrm{km}^{2}$ dan panjang pantai $185 \mathrm{~km}$. Dengan adanya pemekaran wilayah kabupaten sesuai Undang-Undang Nomor 25 Tahun 2008, kini provinsi Jambi terbagi menjadi 9 kabupaten dan 2 kota, yaitu kabupaten Batanghari, kabupaten Bungo, kabupaten Kerinci, kabupaten Merangin, kabupaten Muara Jambi, kabupaten Sarolangun, kabupaten Tanjung Jabung Barat, kabupaten Tanjung Jabung Timur, kabupaten Tebo, kota Sungai Penuh dan kota Jambi (Poerwaningsih, 2013: 3).

Menurut Tanudjirjo (2004:5-7) berita pertama tentang Jambi datang dari kitab sejarah Dinasti Tang (618-906 M) yang menyebutkan kedatangan utusan kerajaan Mo-lo-yue ke Cina pada tahun 644 dan 645 Masehi. Nama Mo-lo-yue ini dapat dikaitkan dengan sebuah kerajaan tertua bernama Melayu di pantai timur Sumatera yang berpusat di sekitar kota Jambi. Seorang pendeta Budha (I-tsing) mengisahkan bahwa pada tahun $671 \mathrm{M}$ dia tinggal untuk di Mo-lo-yeu sambil memperdalam bahasa sansekerta ketika dalam perjalanan dari 
Kanton sebelum ke Nagapattam di India. Kemudian I-tsing singgah lagi di Mo-lo-yeu ketika pulang dari India pada tahun $685 \mathrm{M}$, dikatakan bahwa Kerajaan Melayu telah menjadi She-li-fo-she atau Sriwijaya.

Pengusaan Sriwijaya atas Jambi berlangsung cukup lama. Kitab sejarah Dinasti Sung (960-1279) menyebutkan bahwa Chan-pei pada masa itu adalah juga merupakan tempat kediaman raja. Peran Jambi pada masa lalu tampak dari banyaknya temuan barang import di Situs Percandian Muara Jambi, baik dalam konteks interlokal maupun internasional.

Bukti-bukti yang berupa kebudayaan material (monumen, arca, relief, prasasti dan lain-lain) yang ditemukan di pulau Sumatera banyak yang memperlihatkan jejak agama Buddha Mahayana, dan terbatasnya pengaruh agama Hindu (Supartha, 2009: 54). Menurut P.J. Zoetmoulder, dalam salah satu karangannya "The Significance of the Study of Culture and Religion for Indonesia Historiography" menyebutkan bahwa tiada satupun kebudayaan di dunia ini yang lepas dari pengaruh agama. Hal ini tentu saja juga berlaku untuk kebudayaan Indonesia Klasik, termasuk di dalamnya situs Muara Jambi (Mundardjito, 2009: 39).

Yang disebut Situs Muara Jambi adalah suatu wilayah yang mengandung temuan arkeologis di daerah Muara Jambi, yang membentang sepanjang lebih kurang tujuh kilometer dengan candi Kotomahligai berada di ujung paling barat dan menapo No.1 di ujung sebelah timur. Di daerah sepanjang tujuh kilometer inilah nenek moyang diduga telah bertempat tinggal dan melakukan aktivitas mereka ratusan tahun yang lalu (Mundardjito, 2009: 37).

Menurut Utomo (2011: 134) situs Muara Jambi secara administratif terletak di desa Muara jambi, kecamatan Marosebo, kabupaten Muara Jambi, provinsi Jambi dan secara astronomis terletak pada koordinat $103041^{\prime} 15^{\circ}$ BT dan 1028'310 LS. Situs Muara Jambi yang ketinggiannya sekitar 14 meter
d.p.I terletak di suatu daerah dataran yang merupakan daerah tanggul alam dari sungai Batanghari. Situs percandian Muara Jambi mempunyai luas sekitar 11 kilometer persegi. Situs percandian Muara Jambi ini memiliki 82 buah peninggalan purbakala berupa candi, kolam dan manapo. Sedangkan yang telah dilakukan kegiatan rekonstruksi baru sebanyak 8 bangunan purbakala diantaranya candi Tinggi, candi Gumpung, candi Astano, candi Kembar Batu, candi Kedaton, candi Teluk, candi Gedong II dan candi Gedong 1.

Alam semesta sebagai keseluruhan yang struktural skematis dari hasil perenungan manusia secara filsafat disebut dengan kosmologi. Juga dapat dinamakan etnologi, didalam ilmu kosmologi diterapkan dari segi pembangunan merekontruksi fenomena-fenomena mengarah tujuantujuannya yaitu pembangunan daerah tertentu (Moertono, 1980: 19).

Dalam mitologi Hindu-Budha, gunung Meru adalah sebuah gunung di pusat jagad yang berfungsi sebagai pusat bumi. Gunung tersebut muncul dari dalam bumi dan mencapai tingkat tertinggi surga. Gunung juga merupakan tempat tinggal para dewa. Oleh karenanya gunung kosmis merupakan lambang alam semesta (Ardika, 2002: 58).

Oleh karenanya Plato dan Aristoteles mengatakan bahwa filsafat timbul atas dasar rasa heran. Rasa heran itu sebenarnya merupakan latar belakang mitos-mitos kosmogonis dan mitos-mitos kosmologis. Hasil penyelidikan filsuf-filsuf dapat disingkat dengan tiga ucapan. Alam semesta merupakan keseluruhan yang bersatu, akibatnya harus diterangkan dengan menggunakan satu prinsip saja. Alam semesta dikuasi oleh suatu hukum. Kejadian-kejadian dalam alam tidak kebetulan saja, tetapi ada semacam keharusan di belakang kejadian-kejadian itu. Akibatnya, alam semesta merupakan kosmos. Kata Yunani ini boleh diterjemahkan sebagai "dunia" tetapi artinya 
lebih tepat lagi adalah "dunia yang teratur" (Bertens, 1999: 41).

Menurut Notonagoro dalam Hariyono, (2001:13-15) kosmologi membahas alam semesta ditinjau dari sudut keseluruhan, yang menyangkut masalah tata tertib alam semesta, asal-mula alam semesta, masalah kesempurnaan alam semesta. Ditinjau dari konsep kosmologi seperti pengambilan tentang tata ruang dan waktu oleh karena itu adapun masalah-masalah dan pengolahan kosmologi menurut $F$. Tauler adalah (tata ruang, dan waktu) hubungan antara ruang dan waktu ini langsung menuju pada persoalan apakah ruang dan waktu sungguh-sungguh merupakan suatu hal yang terdapat diluar benda-benda dan peristiwa-peristiwa di dalamnya.

Pengertian kosmos dari percandian Muara Jambi digambarkan dalam bentuk arsitektur candi yang merupakan replika dari jagad raya (Utomo, 2011: 166).

\section{B. METODE PENELITIAN}

Metode penelitian deskriptif kualitatif, yang menggunakan cara mengumpulkan sumber-sumber secara sistematis dan menggunakan sumber data secara mendalam. Penelitian deskriptif kualitatif diuraikan dengan kata-kata menurut responden, apa adanya sesuai dengan pertanyaan penelitiannya, kemudian dianalisis dengan kata-kata apa yang melatar belakangi responden berperilaku (berpikir, berperasaan, dan bertindak) seperti itu tidak seperti lainnya, direduksi, ditriangulasi, disimpulkan (diberi makna oleh peneliti), dan diverifikasi (dikonsultasikan kembali kepada responden dan teman sejawat. Minimal ada tiga hal yang digambarkan dalam penelitian kualitatif, yaitu karakteristik pelaku, kegiatan, atau kejadian-kejadian yang terjadi selama penelitian, dan keadaan lingkungan atau karakteristik tempat penelitian berlangsung (Usman, 2014: 130).

Metode penelitian dinamakan sebagai metode baru, karena popularitasnya belum lama, dinamanakan postpositivistik karena berlandaskan pada filsafat postpositivisme. Metode ini disebut lebih bersifat seni (kurang terpola), karena disebut dengan metode interpretive karena data hasil penelitian lebih berkenaan dengan interprestasi terhadap data yang ditemukan di lapangan (Sugiyono, 2013: 13-14).

\section{HASIL DAN PEMBAHASAN Candi Gedong I Muara Jambi Letak Candi Gedong I}

Desa Muara Jambi merupakan daerah yang menjadi pusat dari adat dari marga Marosebo. Marga Marosebo adalah kelompok masyarakat yang merupakan penduduk asli yang telah menempati wilayah ini dan Marosebo saat ini menyebar di beberapa kampung asli yang pada saat ini berbentuk desa. Beberapa kampung asli itu antara lain Kunangan, Talang Duku, Tebat Patah, Kemingking Dalam, Jambu, Duson Mudo, Sekumbung dan Muara Jambi. Desa Muara merupakan desa yang memiliki bentangan alam di belah oleh aliran sungai Batanghari yang melewati wilayah desa ini. Secara astronomis desa ini berada pada $103^{\circ} 22^{\prime}$ BT hingga $103^{\circ} 45^{\prime}$ BT dan 10 24' LS hingga 10 33' LS (Mundardjito, 2009: 8-11).

Menurut Latief (1994:42) berdasarkan penelitian secara geologis terhadap daerah Jambi dan sekitarnya, dataran di sekitar sungai Batanghari merupakan dataran hasil endapan aluvial limbah banjir. Daerah ini diperkirakan dahulunya pelabuhan yang cukup ramai. Berdasarkan catatan sejarah yang pernah dibuat atau ditulis oleh para musafir Arab dan Cina yang singgah di sungai Batanghari, di antaranya dalam kitab dinasti Tang disebutkan tentang datangnya utusan dari negara Mo lo yu ke tanah Cina pada tahun 644-655 Masehi. Mo lo yu dapat diidentifikasikan dengan Melayu yang terletak di pantai Timur. Untuk menuju situs percandian Muara Jambi dapat menggunakan jalur darat.

Ada dua pilihan rute darat yaitu (1) kota Jambi- jembatan Batanghari I-jalan 
lintas timur Sumatera-simpang setiris-desa Muara Jambi-percandian Muara Jambi dan (2) kota Jambi-Talang Duku-desa Muara Jambi seberang-menyebrangi sungai Batanghari-desa Muara Jambi-percandian Muara Jambi. Untuk rute pertama, kondisi jalan raya lebar dan mulus hanya dapat dinikmati sampai simpang setiris. Sesudah itu kondisi jalan yang sempit dan berlubang sampai ke komplek situs. Rute kedua, hanya dapat digunakan oleh sepeda motor karena tidak ada jembatan untuk menyebrang sehingga menggunakan rakit untuk mengangkut kendaran.

\section{Candi Gedong I}

Candi adalah salah satu peninggalan budaya dari zaman purba di Indonesia. Di provinsi Jambi terdapat komplek percandian Muara Jambi yang salah satunya adalah candi Gedong I yang berlokasi di kabupaten Muara Jambi. Situs percandian Muara Jambi secara astronomis terletak pada koordinat $103^{\circ} 41^{\prime} 15^{\prime \prime}$ BT dan $1^{\circ} 28^{\prime} 31^{\prime \prime}$ LS. Untuk mencapai lokasi situs dapat menggunakan kendaran bermotor melalui desa Kasang, menyeberangi jembatan Batanghari II, melalui jalan menuju Tungkal, kemudian membelok melalui jalan yang langsung menuju desa Muara Jambi (Utomo, 2011:57). Situs percandian Muara Jambi adalah suatu wilayah berisi temuan purbakala, yang membentang sepanjang lebih kurang tujuh kilometer dengan bukit Sengalo berada di ujung Barat dan Menapo Buluran Dalam di ujung sebelah Timur. Batas sebelah Utaranya rawa-rawa dan batas Selatannya adalah sungai Batanghari (Tanudjirjo, 2004: 3).

Kawasan percandian Muara Jambi merupakan peninggalan dari kerajaan Melayu Kuno, dan satu-satunya peninggalan masa Hindu-Budha (abad 7-13 Masehi) yang terluas di Indonesia. Kawasan percandian Muara Jambi terdiri dari reruntuhan bangunan kuno, di antara candi yang telah dibuka dan dilakukan penanganan pelestarian secara intensif yaitu candi Gumpung, candi Tinggi I, candi Tinggi II, candi Kembar Batu, candi Astano, candi Gedong I, candi Gedong II dan candi Kedaton. Kawasan ini juga didukung lingkungan alam dan sosial yang masih terjaga dengan baik (Jurnal Mahasiswa Universitas Padjadjaran, 2012: 2).

Komplek situs Muara Jambi merupakan komplek bangunan suci Budha yang berupa stupa. Stupa adalah sebuah benda atau bangunan suci pada agama Budha. Bentuknya merupakan sebuah bangunan kubah, berdiri di atas sebuah alas dan sebuah tiang puncak di atasnya. Dalam perkembangan agama Budha selanjutnya bentuk stupa itu ikut sedemikian rupa, tidak hanya merupakan sebuah benda kecil dan sederhana, tapi berkembang sebuah bangunan besar yang dianggap suci. Fungsinya juga berkembang dari tempat penyimpanan benda-benda sang Budha dan bhiksu terkemuka menjadi benda atau bangunan suci agama Budha (Nazir, 1981: 31).

Candi Gedong I merupakan salah satu kompleks bangunan suci agama Buddha Mahayana. Para penziarah datang untuk melakukan upacara. Diduga para penziarah itu datang dan bermalam di bagian luar tembok keliling bangunan suci. Ekskavasi arkeologi yang dilakukan di bagian luar tembok keliling situs Muara Jambi banyak menemukan anglo berbentuk sepatu. Anglo jenis ini biasa dibawa-bawa. Kompleks Muara Jambi kini dimanfaatkan kembali oleh umat Buddha dari daerah Jambi. Tidak tertutup kemungkinan umat Buddha dari tempat lain di Sumatera maupun luar Sumatera (Utomo, 2011:37).

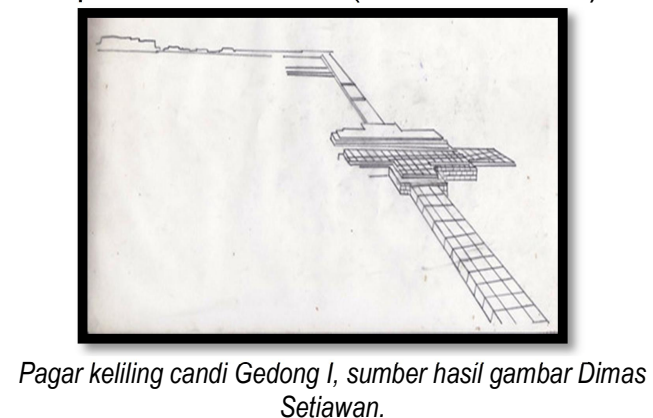


Beberapa hal menarik dari kompleks percandian di Muara Jambi ini adalah seluruh bangunan percandian dibuat dari batu bata. Suatu keadaan yang mirip dengan umumnya bangunan candi-candi di Jawa Timur. Dari keadaan lingkungan dan bangunannya terlihat bahwa pendukung atau pembuat bangunan percandian Muara Jambi ini memiliki tingkat penguasaan teknologi yang sudah relatif maju. Pada sekeliling dari setiap bangunan selalu diberi pagar tembok dari batu bata dan di sisi bagian luarnya dikelilingi oleh parit-parit yang berukuran besar. Sehingga apabila terjadi banjir yang berasal dari sungai Batanghari ketika air pasang tidak akan membanjiri candi-candi tersebut. Hal ini menunjukkan bahwa para pembuat candicandi tersebut telah menyiapkan suatu sistem pengaturan air yang baik. Teknik atau cara pembangunan candi-candi tersebut mempunyai keistimewaan yakni pada bagian dalam tubuh candi umumnya diisi dengan batu-batu mirip batu pualam dalam ukuran yang kecil dan berwarna putih. Semua batu-batu itu diduga merupakan barang impor sebab di sepanjang sungai Batanghari tidak ditemukan jenis batu pualam tersebut, hanya berupa pasir, dan tanah rawa yang basah (Latief, 1994: 44-45).

\section{Lingkungan Alam Candi Gedong I}

Situs percandi Muara Jambi terletak di tepi sebelah Utara sungai Batanghari, di desa Muara Jambi, kecamatan Sekernan, kabupaten Batanghari, pada koordinat 103014 15" Bujur Timur dan 10 28'31" Lintang Selatan. Lingkungan alam di situs Muara Jambi diketahui berada di sepanjang tepi sungai Batanghari terdapat tanah yang tinggi menyerupai tanggul dan di belakang tanah yang tinggi tersebut terdapat daerah rawa (Anggraeni, 1992: 119).

Kawasan Muara Jambi secara keseluruhan berada di bekas delta purba yang merupakan dataran aluvial pantai Timur Sumatera bagian Selatan. Secara terinci kawasan ini dapat dibedakan menjadi tiga satuan bentuk lahan yaitu tanggul alam resen, rawa belakang dan tanggul alam subresen yang letaknya berurutan di sepanjang tepi sungai Batanghari. Tanggul alam merupakan bentuk lahan yang terjadi dari materi endapan sungai Batanghari akibat banjir yang selalu terjadi selama ribuan tahun. Tanggul alam umumnya lebih tinggi dari daerah sekelilingnya dan pembentukannya tetap berlangsung hingga sekarang. Akibatnya daerah belakang tanggul alam menjadi lebih rendah dan selalu tergenang air. Genangan inilah yang disebut rawa belakang, oleh karena sepanjang sejarahnya sungai Batanghari seringkali berpindah-pindah, maka selain tanggul resen terdapat pula tanggul alam subresen (lama) yang secara kronologis lebih dahulu terbentuk (Tanudjirjo, 2004: 17).

Secara keseluruhan wilayah desa Muara Jambi berada pada ketinggian 8 hingga 12 meter dari permukaan laut. Berdasarkan ketinggian ini lingkungan alam desa Muara Jambi merupakan dataran rendah. Dilihat secara keseluruhan berada di daerah kawasan dataran rendah hutan tropis Sumatera (Mundardjito, 2009: 9). Sebagai daerah yang beriklim tropis basah, lingkungan flora situs Muara Jambi umumnya berupa hutan hujan tropis yang pohon-pohonya memiliki ketinggian tajuk rata-rata 20 meter dari permukaan tanah. Tingkat kelembapan yang tinggi menyebabkan proses pembusukan cepat terjadi, walaupun demikian tanah hutan tidak dapat dikatakan subur karena kandungan haranya mengalami pencucian intensif sebagai akibat dari tingginya curah hujan. Itulah sebabnya permukaan hutan merupakan tempat yang cocok bagi pertumbuhan berbagai jenis tanaman semak berdahan lunak yang membutuhkan sinar matahari untuk mempertahankan hidup. Pada daerah rawa vegetasi situs Muara Jambi terdiri dari pohon-pohon bertanjuk 5 hingga 15 meter. Termasuk tanaman perdu 
yang tahan terhadap keasaman di atas normal dan hidup di daerah genangan yang tidak terlalu dalam.

Menurut Tim Koordinasi Penelitian Sejarah Melayu Kuno (1994: 34) sebagian besar lingkungan candi Gedong I masih merupakan hutan primer. Banyak pohon durian dan duku yang tajuknya tinggi tumbuh cukup rapat di sekitar candi. Pada daerah yang semula berupa hutan saat ini perlahan-lahan telah berubah menjadi lahan perkebunan dan ladang. Lahan perkebunan umumnya terdiri dari tanaman karet, kelapa sawit, coklat, kebun buah; duku, durian, nangka, manggis, rambutan, jeruk dan pisang. Pembukaan ladang baru umumnya ditanami tanaman sayur-sayuran, seperti kacang panjang, mentimun, cabe, terong, ubi kayu dan jagung. Sedangkan pada daerah rawa sebagian besar telah berubah menjadi sawah dengan tanaman padi dan sebagian kecil yang tersisah belum dimanfaatkan (Tanudjirjo, 2004: 17-18).

Keadaan tanah yang relatif sempit dengan lebar tanggul rata-rata tujuh ratus meter, menyebabkan tinggalan-tinggalan arkeologis sebagian besar terakumulasi pada daerah-daerah tinggi yang bebas genangan air, sehingga tidak mengherankan bila pada akhirnya pola pemukiman di Muara Jambi mempunyai corak linier mengikuti bentangan alam tanggul. Pada areal seputar situs terdapat beberapa sungai kecil yang mengelilingi candi Gedong I tersebut. Sungai-sungai kecil ini ada yang memiliki nama depan "parit" dan "sungai" yang merupakan hasil buatan manusia dan berfungsi sebagai kanal (Mundardjito, 2009: 38).

Sungai-sungai kecil atau parit-parit tersebut menunjukan tanda seolah-olah memisahkan kelompok percandian di Muara Jambi menjadi tiga kelompok. Kelompok pertama terletak di sebelah Timur terdiri dari candi Astano, candi kembar Batu, candi Tinggi dan candi Gumpung yang dipisahkan oleh sungai Melayu di sebelah Barat dan Utara, serta sungai Buluran di sebelah
Selatan. Kelompok kedua terdiri dari candi Gedong I, candi Gedong II dan candi Kedaton yang terletak di tengah, yang seolah-olah dipisahkan oleh sungai Melayu di sebelah Timur dan sungai Terusan di sebelah Barat. Kelompok ketiga adalah candi Koto Mahligai yang terletak menyendiri di ujung Barat Laut dengan batas sungai Berembang di sebelah Barat (Mundardjito, 2009: 37).

Di sebelah Utara komplek candi Gedong I terdapat parit Sekapung yang mengalir dari Timur ke Barat. Aliran parit dimulai dari sungai Melayu di bagian Timur dan berakhir di sungai Terusan di bagian Barat. Di sepanjang parit Sekapung sisi Selatan merupakan lokasi berdirinya bangunan-bangunan candi, seperti candi Gedong I dan Gedong II serta reruntuhan bangunan kuno yang masih berwujud menapo yaitu menapo Sekapung I, menapo Parit Duku, menapo Raman, menapo Kunyit dan menapo Kerawe. Pada sisi Utara juga terdapat gundukan tanah, namun di dalamnya tidak terdapat reruntuhan bata, yaitu menapo sungai Melayu III, menapo parit Sematang Tubo, parit Sekapung II dan menapo Pandir. Menapo-menapo ini hanya gundukan tanah dan dikelilingi parit sebatas luas gundukan tanahnya (Mundardjito, 2009: $5)$.

\section{Kondisi Umum Lingkungan Candi Gedong I}

Konsep sentral dalam suatu sistem kepercayaan adalah yang berkenaan dengan apa yang dapat disebutkan sebagai kebenaran hakiki atau kebenaran tertinggi. Nilai-nilai kepercayaan sangat bergantung kepada konsep mengenai hakikat hubungan antara manusia ataupun seluruh isi alam semesta dengan Tuhan tersebut. Semua sistem kepercayaan memancangkan tujuan umat yang terpenting adalah untuk menyatu atau mendekatkan diri dengan Tuhannya yang merupakan kebenaran hakiki itu. Dalam perkembangan agama Budha konsep Sunyata adalah menuntut suatu 
penghayatan spiritual yang berbeda pula, yaitu bahwa yang sebenar-benarnya ada hanyalah ketiadaan. Dengan demikian maka segala yang tampak seperti ada sebernya tidaklah ada, atau disebut maya (Sedyawati, 2014: 179-180)

Menurut Umar Khayam dalam Dharsono (2007: 30) berpendapat hubungan mikrokosmos dan makrokosmos, bahwa mikrokosmos sebagai jagad kecil merupakan jagad yang harus diupayakan terus keselarasannya, keselarasan hubungan antara batin dan jasmaninya. Jagad kecil sebagai unsur bagian jagad besar harus juga terus menjaga agar hubungannya dengan unsur-unsur lain dari jagad besar tetap selaras. Adapun jagad besar, menurut pandangan orang Jawa, terdiri dari segala macam unsur baik yang terlihat maupun yang tidak terlihat oleh mata. Manusia, para lelembut, roh halus, roh para cikal bakal para pendiri desa, tumbuh-tumbuhan, batu-batuan, gunung, dan sungai adalah unsur-unsur jagad yang berada dalam hubungan keteraturan.

\section{a. Konsep Gunung}

Dalam pandangan masyarakat tradisional, dunia terdiri dari tiga tingkatan. Pertama adalah dunia di mana kita hidup, kedua dunia atas (surga) dan ketiga dunia bawah (yang sering diibaratkan sebagai dunia hitam. Pembagian dunia tersebut dalam wujud fisik sering disimbolkan sebagai: kapala, badan dan kaki dalam bangunan. Atau gunung, daratan dan laut dalam lingkungan binaan (Handinoto, 2015: 19).

Gunung dilambangkan sebagai keseluruhan alam semesta (makrokosmos) dan tempat bertahtanya Tuhan. Gunung yang dilambangkan sebagai penjelmaan Tuhan, kemudian dianggap sebagai tempat yang paling sakral, puncak segala tempat kesucian dan tempat bertemunya manusia dengan Tuhan. Dalam pandangan agama Budha, konsepsi negara itu difungsikan keberadaannya untuk menghadirkan kesejahteraan bagi agama. Jika eksistensi negara sebagai struktur politik yang secara fungsional tidak mampu mengemban tugas menyejahterakan agama, maka kehadiran negara dapat dibatalkan eksistensinya (Masroer, 2004: 22-23).

Menurut Wirjomartono (2009: 171172) secara keseluruhan candi melambangkan makrokosmos satu alam bawah (bhurloka, kamaloka, kamadhatu) tempat manusia yang masih dipengaruhi nafsu; alam antara (bhurvaloka, rupaloka, rupadhatu) tempat manusia telah meninggalkan keduniawian dan dalam keadaan suci menemui Tuhannya; dan alam atas (swahloka, arupaloka, aruphadatu) tempat dewa-dewa. Candi sebagai tempat sementara bagi dewa merupakan bangunan tiruan tempat dewa seperti yang berada di Gunung Mahameru. Oleh karena itu, candi diberi motif hiasan yang berhubungan dengan alam khayangan seperti bungabunga teratai, binatang-binatang dewa-dewa atau bidadari.

Gunung atau kayon merupakan manifestasi dari gunung kosmis dan pohon kehidupan. Berkaitan dengan pandangan masyarakat, tentang gunung yang sudah ada sejak jaman pra-sejarah. Pemikiran tentang gunung senantiasa hadir dalam penggambaran secara visual maupun secara tekstual. Bahkan dalam kebudayaan Hindu-Budha gunung dipergunakan sebagai analogi perspektif hubungan mikrokosmos dan makrokosmos. Kondisi lingkungan masyarakat Indonesia, memberikan kemungkinan munculnya inisiasi pemujaan terhadap gunung. Gunung yang menjulang tinggi, agung dan penuh misteri dianggap memiliki kekuatan supranatural, sehingga pantas dikeramatkan.

Sikap dan pandangan "mengkeramatkan gunung" inilah yang memberi kemungkinan menimbulkan munculnya berbagai mitos dan pemujaan terhadap gunung. Konsep gunung tersebut juga berpadu dengan konsep dunia atas, dunia tengah dan dunia bawah. Dunia atas adalah alam roh nenek moyang 
(kepercayaan lama), kahyangan atau Nirwana (Hindu-Budha) dan Surga (Islam). Dunia tengah adalah alam antara (medium) dari dunia atas dan bawah. Sedangkan dunia bawah adalah bumi dan seisinya (Dharsono, 2007: 19-22).

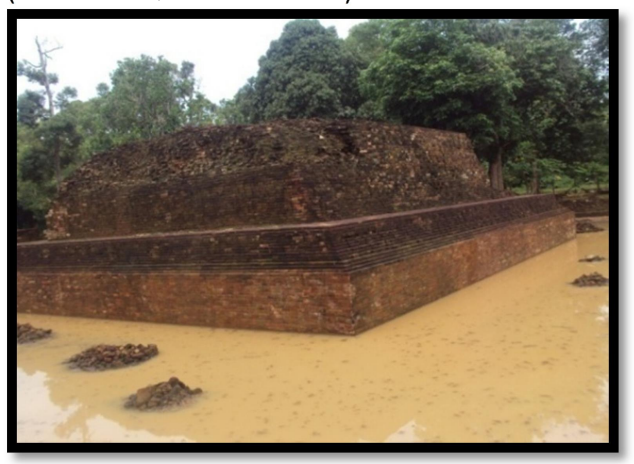

Candi Induk Gedong I Muara Jambi, Hasil Dokumentasi Desi Efrili Yani

Menurut Wirjomartono (2009: 171 172) secara keseluruhan candi melambangkan makrokosmos satu alam bawah (bhurloka, kamaloka, kamadhatu) tempat manusia yang masih dipengaruhi nafsu; alam antara (bhurvaloka, rupaloka, rupadhatu) tempat manusia telah meninggalkan keduniawian dan dalam keadaan suci menemui Tuhannya; dan alam atas (swahloka, arupaloka, aruphadatu) tempat dewa-dewa. Candi sebagai tempat sementara bagi dewa merupakan bangunan tiruan tempat dewa seperti yang berada di Gunung Mahameru. Oleh karena itu, candi diberi motif hiasan yang berhubungan dengan alam khayangan seperti bungabunga teratai, binatang-binatang dewa-dewa atau bidadari.

\section{b. Konsep Sungai}

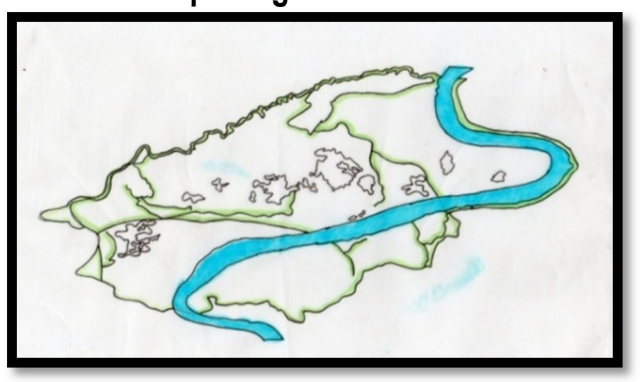

Sungai Batanghari di kawasan situs Muara Jambi, sumber hasil gambar Desi Efrili Yani
Sungai atau parit merupakan satu kesatuan berlandaskan konsepsi kosmologis dalam kepercayaan Budhisme (Mundardjito, 2009: 1). Jaringan parit/kanal kuno yang ada di kawasan percandian Muara Jambi adalah sungai Melayu, sungai Terusan, sungai Jambi, parit Johor, parit Sekapung, sungai Buluran Dalam, sungai Buluran Keli, Buluran Paku dan sungai Selat. Jaringan kanal ini terhubung dengan anak-anak sungai yang berada di DAS Batanghari dan mengalir melewati kawasan percandian Muara Jambi. Anak sungai tersebut anatara lain, sungai Seno, sungai Amburan Jalo dan sungai Berembang. Sebagai simpul jaringan kanal, sungai Berembang memegang peranan penting karena aliran kanal-kanal kuno menyatu dengan sungai Berembang sebelum akhirnya bermuara di sungai Batanghari (Mundardjito, 2009: 4).

Sungai Batanghari, parit-parit, kolam dan danau yang mengalir dan berada dikawasan situs Muara Jambi merupakan bagian yang tidak terpisahkan dari dataran tempat berdirinya bangunan suci. Sungai Batanghari sebagai jalur pelayaran merupakan penghubung kawasan situs Muara Jambi dengan masyarakat di daerah Jambi dan sekitarnya. Serta dunia luar yang ada di nusantara mupun orang asing seperti Cina, India bahkan bangsa dari Asia Tengah. Lebih jauh parit kuno yang dibangun bersamaan dengan masa pembangunan percandian merupakan kesatuan landscape berupa jaringan tata guna air, saling berpotongan dan membentuk sebuah "sabuk pelindung" di situs Muara Jambi. Dalam hal ini secara simbolis fungsi parit merupakan batas antara yang sakral dan profan. Dataran yang disucikan sifatnya terikat dan dikhususkan sebagai tempat berdirinya bangunan-bangunan candi berada di dalam jaringan parit. Sebaliknya dataran di luar jaringan lebih bersifat longgar dan tidak secara khusus diperuntukan sebagai lokasi bangunan candi. Parit tersebut secara 
fungsional digunakan untuk mendukung lingkungan hidup masyarakat yang berdiam dan datang ke candi Gedong I dan secara simbolis juga terkait dengan simbolisme dunia makrokosmos dan mikrokosmos dalam mitodologi agama Budha. Dalam hal ini keberadaan parit di candi Gedong I mempunyai makna sebagai replika perlambang samudera dan gunungnya sendiri diwujudkan dalam gugusan bangunan candi (Mundardjito, 2009: 7).

\section{Kondisi Khusus Lingkungan Candi Gedong I}

Gambaran hubungan mikro kosmos (batin manusia) menggambarkan eksitensi lahiriah, jasmaniah dan eksitensi batiniah. Tujuan hidup manusia adalah mementingkan aspek batiniahnya, agar aspek lahiriahnya menjadi teratur dan mencapai harmoni dengan hakekat. Manusia harus menyatu dengan makro kosmos, dan di dalam kesatuan dengan makro kosmos manusia dapat menemukan jati dirinya. Pandangan tentang makro kosmos mendudukan manusia hanya bagian dari semesta. Manusia harus menyadari tempat dan kedudukannya dalam jagad raya ini, sadar dimana tempat dan perannya dalam tata kehidupan masyarakat dan tata kehidupan alam semestanya (Dharsono, 2007: 14).

Penerapan asas mikro kosmoshierarkis bertujuan untuk membedakan ruang sakral dan ruang profan. Sedangkan penerapan asas mikro kosmos-dualistis bermaksud menyucikan ruang (yang tak terbatas) secara mutlak. Makna dari konsep tata ruang ialah bahwa di dalam konsep penataan ruangnnya yang paling diuatamakan bukan batas teritorial, tapi struktur hubungan antar elemen-elemen pembentuk ruang. Sitem kemasyarakatan pada umumnya mempunyai dua macam dasar. Pertama adalah dasar religius sakral dan kedua adalah dasar politis profan. Ruang sakral perlu diberi batas (dibatasi) dari ruang profan. Di dalam ruang sakral (mikrokosmos) tersebut manusia bisa menata secara teratur berdasarkan kosmologi dari penghuninya. Untuk penata lingkungan binaan diperlukan kosmografi sebagai pedomannya. Upaya untuk menghadirkan dalam bentuk fisik tersebut dinyatakan dalam perancangan wilayah dan tata bangunan seperti wujud elemen fisik (Handinoto, 2015: 17-18).

Di dalam arsitektur, hierarki dinyatakan dalam penataan berbagai bentuk. Cara untuk menyatakan hierarki dalam arsitektur di antaranya adalah dengan menggunakan lantai dan dinding sebagai pembatas. Makin tinggi lantainya, maka tinggi tingkatan hierarkinya. Sedangkan tembok-tembok pagar keliling dipakai untuk membatasi suatu daerah dengan daerah lainnya dalam tingkatan hierarki yang berbeda. Konsep mikrokosmos hierarki digunakan dalam penataannya. Sumbu atau poros dapat berfungsi sebagai orientasi dan elemen penyatu serta sekaligus sebagai batas dalam mengklasifikasikan hierarki penataan ruang (berdasarkan kosmografi) di dalam ruang sakral (Handinoto, 2015: 21).

Konsep dasar rancangan candi klasik Indonesia adalah keinginan menciptakan tiruan gunung pada pusat alam semesta, tempat roh para dewa dapat dibujuk untuk menjelma menjadi patung atau lingga yang ditempatkan dalam ruangan yang menyerupai gua. Arsitektur Indonesia Klasik paling awal terdiri atas tempat suci Hindu, dibangun di gunung api di Jawa Tengah. Secara raga dan perlambang, bangunan ini bersandar pada kepercayaan bahwa gunung merupakan tempat kekuatan adikodrati. Setelah "elit" yang berkuasa mulai membangun dengan batu, tempat bangunan mulai menyebar ke dataran rendah. Perluasan ini mungkin berasal dari paduan semangat: keinginan membuat tempat keagamaan lebih mudah dicapai masyarakat umum dan pengakuan untuk "elit" yang berkuasa bahwa hubungan dengan kekuasaan dewa secara nyata menambah kekuasaan duniawi mereka. 
Beberapa prinsip dasar yang melatar belakangi bentuk candi Indonesia adalah kepercayaan pribumi pada kekuatan yang ada dalam nenek moyang dan gunung. Meski agama dan arsitektur India memainkan peran tambahan dalam menghias dan bentuk baru dalam mengungkapkan konsep yang ada sebelumnya, teori India tentang setangkup sebagai unsur dasar tata semesta secara nyata menambah konsep prasejarah Indonesia. Seni "klasik" menekankan setangkup dan penempatan unsur-unsur secara tepat, masing-masing dengan tempat yang telah seluruhnya ditentukan dalam susunan (Arismunandar, 2002: 52).

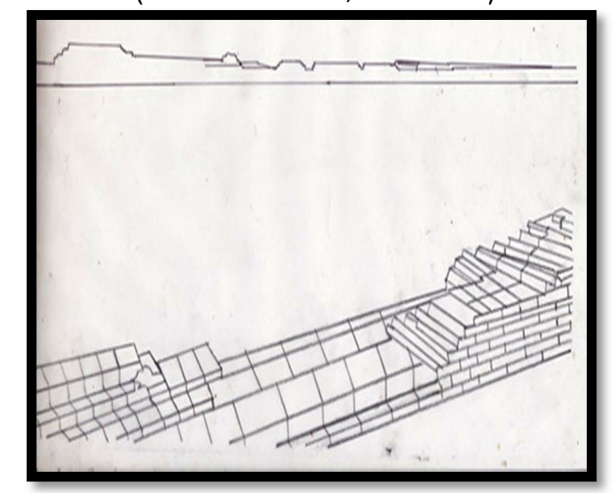

Pagar keliling candi Gedong I Muara Jambi, sumber hasil gambar Dimas Setiawan

Bangunan candi Gedong I dikelilingi tembok pagar keliling dengan ukuran $65 \mathrm{x}$ 85 meter. Di tengah halaman yang membujur arah Barat-Timur, agak kearah Barat, terdapat runtuhan bangunan candi yang berdenah bujur sangkar dengan ukuran 14,5 x 14,5 meter. Runtuhan tangga naik terletak di sisi Timur. Demikian juga runtuhan bangunan gapura pintu masuk halaman candi terletak di sisi Timur. Keadaan permukaan dinding kaki bangunan sudah sangat rusak. Bagian yang masih tersisah ditemukan pada tangga naik. Pada bagian ini ditemukan hiasan yang berbentuk salib (Utomo, 2011:154).

\section{Makna Kosmologi Candi Gedong I dalam Agama Budha}

Gambaran mengenai kosmos dalam setiap sistem kepercayaan dapat dipilih antara yang berkenaan dengan struktur kosmos yang dapat juga disebut sebagai kosmografi dan yang berkenaan dengan proses-proses dalam kosmos yang disebut sebagai kosmogoni. Berkenaan dengan struktur kosmos dapat dideskripsikan berdasarkan struktur vertikal maupun horisontal. Struktur vertikal berkaitan dengan konsep dunia atas dan dunia bawah sedangkan struktur horisontal berkaitan denagn arah mata angin beserta pandangan-pandangan atau nilai-nilai khusus berkenaan dengan masing-masing arah itu (Sedyawati, 2014: 471)

Dalam alam pikiran masyarakat tradisional yang religius, manusia selalu membagi wilayahnya menurut keaktifannya. Keaktifan mana yang disebut sebagai sakral dan mana yang dianggap sebagai profan. Di dalam ruang yang yang sakral, segalanya teratur, baik tingkah laku penghuninya maupun struktur bangunannya. Sedangkan di ruang yang profan semuanya serba kacau karena tidak atau belum disucikan. Gambaran atau citra terhadap dunia (makro kosmos), ikut menentukan tatanan mikro kosmos yang akan diwujudkan dalam penataan wilayah, ibukota, komplek keraton maupun bangunan pada umumnya. Gambaran atau citra makro kosmos menurut doktrin Budhisme terdiri dari "gunung Meru menjadi pusat dari jagat raya. Gunung ini dikelilingi oleh tujuh barisan pegunungan. Masing-masing pegunungan ini dipisahkan oleh tujuh buah samudra yang berbentuk cincin. Di luar rantai pegunungan terakhir terletak lautan dan di dalam lautan ini dijumpai empat buah benua, masingmasing pada penjuru angin. Benua yang terletak di Selatan gunung Meru adalah Jambudwipa, tempat tinggal umat manusia. Jagad raya itu pun dikelilingi oleh sebuah dinding besar yang terdiri dari batu karang, disebut barisan cakrawala. Pada lereng gunung Meru terletak swarga (surga) yang terendah, yaitu swarga dari keempat raja 
besar atau penjaga dunia. Pada puncaknya swarga kedua, yaitu swarga ke-33 dewa serta Sudarsana, kota dewa-dewa, tempat Indra bersemayam sebagai raja. Di atas gunung Meru terdapat lapisan-lapisan lainnya dari kayangan" (Handinoto, 2015: 12-15).

Menurut Handinoto (2015:12-13) manusia tradisional, menganggap bahwa kosmos (bumi) merupakan sesuatu yang sakral (karena kosmos adalah dunia yang tertata). Sedangkan di luar itu adalah chaos', dianggap sebagai ruang profan. Untuk memudahkan penataan ruang sakral, maka ruang harus dibatasi. Dalam wujud fisik, batas tersebut bisa berupa pagar/tembok kelilingi. Pagar/tembok keliling dalam tata ruang candi berfungsi sebagai batas dari ruang sakral terhadap ruang profan yang ada di luarnya. Sedangkan gerbang (pintu masuk), merupakan ambang peralihan dari daerah sakral ke daerah profan.

Secara umum pintu gerbang dapat berbentuk pintu gerbang tanpa atap (candi/gapura) dan pintu beratap (paduraksa/kori agung). Bentuk dari pintu gerbang mencakup bentuk ukuran, arah hadap, bagian-bagiannya yang dapat dirinci dari bagian kaki, tubuh dan atap yang merupakan komponen utama pada gapura, sedangkan yang merupakan komponen pelengkapnya berupa tangga, pipi tangga, menara sudut dan kemuncak. Bangunan pintu gerbang candi tersebut berfungsi sebagai pintu masuk ke bangunan suci atau pemisah antara bagian yang dianggap sakral dengan bagian yang dianggap profan (Idris dkk, 2016: 7). Di dalam ruang yang sakral segalanya teratur, baik tingkah laku penghuninya maupun struktur bangunannya. Sedangkan di ruang yang profan semuanya serba kacau karena tidak atau belum disucikan. Di dalam ruang sakral yang dibatasi oleh tembok keliling dibuat pengaturan ruang atau massa bangunan berdasarkan klasifikasi yang diatur dalam kosmografi.
Kosmologi adalah ilmu pengetahuan tentang alam ataupun dunia. Dunia dalam penyelidikan kosmologi adalah dunia sejauh yang kita alami seutuhnya. Kosmos berarti susunan atau juga ketersusunan yang baik, khaos yang berarti keadaan kacau balau. Struktur-struktur yang paling mendasar dalam mencari makna dunia berdasarkan kosmologi yaitu meliputi: (1) Dunia menurut eksistensinya (keluasan atau lingkup), mengandung segala macam dunia dengan segala bagian dan aspeknya, sehingga tidak ada apa-apa yang dikecualikan darinya (2) Dunia menurut komprehensinya (kepadatan atau arti) memuat intisari segala dunia lain, sehingga tidak hanya menunjukan aspek ini atau segi itu, melainkan mengungkapkan hakikat sendiri. Menurut filosofis yang bersegi dua itu, dunia diselidiki sejauh merupakan dunia menurut inti dan hakikatnya mutlak atau menurut akarnya (Ronald, 2008: 206).

Sebelum kosmos atau dunia tersusun, semesta ini berada dalam keadaan kacau. Dalam pandang kosmologi penduduk awal penghuni bumi Indonesia ini penataan ruang ada hubungan dengan jagat dalam skala dan hierarki tertentu. Kedudukan manusia ada hubungannya dengan alam semesta amat ditentukan oleh pemahamannya tentang susunan jagad. Jagad raya, jagad kecil hingga ke manusia seakan-akan tersusun dengan suatu tata tertib tertentu. Kosmologi terkait dengan ruang dan secara simbolik seluru lahan dan makhluk yang terkandung di dalamnya (Wirjomartono, 2009: 27-28).

Falsafah Jawa menggambarkan hubungan sistem kehidupan dengan dua macam jagad, yaitu jagad besar (makro kosmos) dan jagad kecil (mikro kosmos). Makro kosmos adalah jagad besar yang mencakup semua lingkungan tempat seseorang hidup, sedangkan mikro kosmos (jagad kecil) adalah diri dan batin manusia itu sendiri. Secara vertikal mengatur hubungan antara batin (mikro kosmos) dengan Tuhannya dan secara horisontal 
mengatur hubungan antara batin (mikro kosmos) dan lingkungan alam semesta (makro kosmos). Pandangan masyarakat Jawa, gunung yang kelihatan tinggi dengan puncak-puncaknya yang tertutup awan, menyimpan banyak misteri dan dianggap memiliki keajaiban oleh manusia di jaman dahulu, sehingga gunung dianggap sebagai sesuatu yang keramat dan masih dikeramatkan sampai kini. Gunung menurut kepercayaan masyarakat (terutama Jawa) adalah jembatan dunia atas dengan dunia bawah, oleh karenanya tempat-tempat pemujaan didirikan di tempat yang tinggi atau diciptakan berbagai prototipe gunung yang disebut gunungan (tiruan gunung) sebagai jembatan trasendental antara dunia atas dengan dunia bawah. Di Indonesia puncak-puncak gunung dipercaya secara luas sebagai tempat tinggal para dewa dan roh-roh leluhur. Menurut pandangan agama Budha, gunung memiliki fungsi penyetabil jagad raya, seolah menahan langit dan bumi, menetralkan kekuatan jahat, kekacauan, ketidakstabilan dan ketidakteraturan (Dharsono, 2007: 56-57).

Di masa agama Budha, terdapat perbedaan yang jelas antara yang ada di "keraton dan sekitarnya" dengan yang ada di "luar keraton". Segala ungkapan budaya yang ada di keraton dan sekitarnya menunjukan masukan yang kuat dari kebudayaan India yang terkait dengan agama Hindu dan Budha. Peninggalanpeninggalan baik tertulis (prasasti dan karya sastra) maupun karya-karya kebendaan (arca dan candi) merujuk pada model India klasik. Demikian pula pada konsep-konsep keagamaan maupun estetika. Diantara konsep keagamaan yang banyak diungkapkan dalam karya-karya sastra adalah mengenai "kebenaran tertinggi" yang dinamakan Kasunyatan, Paramasiwa, Hyang ning hnyang inisti dan Sang Hyang Siwa-Budha.

Konsep-konsep keagamaan yang berkembang di lingkungan keraton mendapat intensifikasi melalui pembangunan sarana dan prasarana peribadatan, seperti candi-candi beserta kelengkapan arca-arcanya. Dalam lingkungan luar keraton pun terdapat candicandi yang merupakan bagian dari sistem percandian 'negara' yang disantuni oleh pihak kerajaan. Namun, di luar itu terdapat pula pusat-pusat rutual keagamaan yang lebih berorientasi kepada apa yang dapat disebut sebagai "warisan kepercayaan lokal", seperti yang terjabarkan dalam bentuk monumen pundak berundak. Di samping pusat-pusat ritual itu, di luar keraton pun berkembang institusi-institusi yang terarah pada pengasuhan kegiatankegiatan pertapaan. Ini pun tak jarang disantuni oleh kerajaan, namun kegiatannya lebih independen terhadap arahan pusat. Institusi-institusi tersebut ada yang fokusnya adalah pada kegiatan pendidikan keagamaan (Sedyawati, 2014: 127-128).

Makna kosmologi pada percandian Muara Jambi, khususnya candi Gedong I digambarkan dalam bentuk arsitektur candi yang merupakan replika dari jagad raya. Pada candi Gedong I terdapat pagar keliling dan di luar pagar terdapat parit atau kanal yang mengelilinginya. Halaman di mana candi berdiri letaknya lebih tinggi dari permukaan tanah di sekitarnya. Hal ini menggambarkan bahwa bangunan candi diumpamakan sebagai gunung Meru (gunung suci tempat tinggal dewa-dewa di mana Indra sebagai raja para dewa), pagar keliling candi yaitu candi Gedong I diumpamakan sebagai rangkaian pegunungan (cakrawala) yang mengelilingi pusat jagad raya dan parit atau kanal yang mengelilingi candi Gedong I diumpamakan sebagai samudera. Penggambaran kelompok percandian seperti itu mempunya dua maksud, yaitu:

a. Sebagai pusat pemujaan, bentuk arsitektur setidaknya harus merupakan penggambaran dari jagad raya dalam bentuk kecil.

b. Sebagai suatu tempat yang dianggap suci, tempat tersebut harus terhindar 
dari hal-hal yang kotor. Ini dikarenakan sungai Batanghari pada setiap musim hujan airnya meluap mengenangi daerah-daerah di sekitar candi. Oleh sebab itu, halaman percandian harus ditinggikan dan dibuat parit atau kanal guna mempercepat kembalinya air limbah ke sungai Batanghari (Utomo, 2011: 165).

Menurut konsep ajaran agama Budha, pemukiman seharusnya terletak di Selatan gunung Meru yang dalam penggambarannya terletak di Selatan bangunan candi atau istana. Di daerah Muara Jambi sisa pemukiman tidak seluruhnya ditemukan di Selatan candi. Di situs Muara Jambi yang letaknya di sisi Utara Batanghari temuan sisa pemukiman sebagian besar ada di Selatan candi. Sedangkan yang letaknya di sisi Selatan Batanghari temuan sisa pemukiman ada di Utara candi. Hal ini dapat saja terjadi, karena pemukiman biasanya mendekat sungai. Dengan demikian penerapan konsep ajaran Budha mengenai gambaran jagad raya tidak ketat, melainkan tergantung pada lingkungan sekitarnya (Utomo, 2011:166-167).

Konsep kosmologi diterjemahkan ke dalam konsep ruang untuk pemukiman yang ideal. Pemukiman yang paling ideal adalah dilatar belakangi oleh pegunungan atau perbukitan dan menghadap ke sungai atau ke laut. Pegunungan atau bukit dianggap sebagai pertahanan terhadap angin yang dapat membawa pergi semua keberuntungan. Sedangkan laut dan sungai dapat digunakan sebagai sarana transportasi (Pratiwo, 2010:21).

\section{SIMPULAN}

Kawasan situs Muara Jambi adalah salah satus kawasan bersejarah terpenting di Indonesia. Di situs ini terdapat bukti dengan adanya kehidupan keagamaan dan kebudayaan klasik masa Sriwijaya dan Melayu Kuno. Selain bangunan candi, ditemukan juga potongan keramik, mata uang Cina, patung, kanal kuno dan manikmanik. Di antara peninggalan ini yang paling penting adalah komplek percandian karena keberadaannya merupakan bukti kehadiran masyarakat yang menetap secara permanen. Bangunan candi yang telah ditemukan sampai saat ini berjumlah sebelas, salah satunya candi Gedong I. Situs candi Gedong I Muara Jambi merupakan kawasan yang dikelilingi oleh aliran sungai atau parit kuno. Aliran parit tersebut dimulai dari sungai Melayu di bagian Timur dan berakhir di sungai Terusan di bagian Barat hingga bermuara di sungai Batanghari. Sungai/parit/kanal tersebut merupakan bagian yang tidak dapat dipisahkan dari dataran tempat berdirinya bangunan suci keagamaan. Hal ini didasari akan pentingnya peran air suci dalam agama Budha. Makna tentang konsep kosmologi candi Gedong I digambarkan dalam bentuk arsitektur candi yang merupakan replika dari jagad raya. Hal ini menggambarkan bahwa bangunan candi diumpamakan sebagai gunung Meru. Pagar keliling candi Gedong I diumpamakan sebagai rangkaian pegunungan (cakrawala) yang mengelilingi pusat jagad raya dan parit atau kanal yang mengelilingi candi Gedong I diumpamakan sebagai samudera.

\section{DAFTAR PUSTAKA}

Anggraeni, Nies. 1992. Laporan Kegiatan Peneliti Arkeologi selama Pelita III. Palembang: Balai Arkeologi Palembang.

Ardika, Wayan Dkk. 2002. Sejarah Awal. Jakarta: PT. Widyadara.

Arismunandar, Agoes, dkk. 2002. Arsitektur. Jakarta: PT. Widyadara.

Bertens, Kees. 1999. Sejarah Filsafat Yunani . Yogyakarta: Kanisius.

Dhakidae, Daniel. Dkk. 2003. Profil Daerah Kabupaten dan Kota Jilit 2. Jakarta: Kompas. 
Dharsono. 2007. Budaya Nusantara Kajian Konsep Mandala dan Konsep TriLoka terhadap Pohon Hayati pada Batik Klasik. Bandung: Rekayasa Sains.

Hadinoto. 2015. Perkembangan Kota di Jawa. Yogyakarta: Ombak.

Hariyono, Budi. 2001. Tabir Misteri Jagat Raya Kajian IImu Kosmologi Surabaya: Putra Pelajar.

Jurnal Mahasiswa Universitas Padjadjaran, Vol. I No I 2012. Hubungan Penggunaan Website Muara jambi Pilgrimage dengan Pemenuhan Kebutuhan Informasi Pengunjung Situs tentang Candi Muara Jambi. Padjadjaran: Universitas Padjadjaran.

Latief, llyas, dkk. 1994. Dampak Pengembangan Pariwisata Terhadap Kehidupan Budaya Daerah Jambi. Jambi.

Masroer. 2014. The History of Java. Yogyakarta: Ar-Ruzz Media.

Moertono.1980.FilsafatKosmologi / Filsafat Alam Semesta.Yogyakarta: Liberty.

Mundardjito. 2009. Muara Jambi Dulu, Sekarang, dan Esok. Palembang: Balai Arkeologi.

Nazir.1981. Arkeologi Klasik Daerah Jambi. Jambi: Museum Negeri Provinsi Jambi.

Poerwaningsih, Andriyatie. 2013. Ensiklopedia Seni dan Budaya Nusantara (Jambi). Bekasi: PT Mentari Utama Unggul.

Ronald, Arya. 2008. Kekayaan dan Kelenturan Arsitektur. Surakarta: Muhammadiyah University Press.

Sedyawati, Edi. 2014. Kebudayaan di Nusantara. Depok: Katalog Dalam Terbitan.

Sugiyono. 2013. Metode Penelitian Kuantitatif, Kualitatif dan Kombinasi (Mixed Methods). Bandung: Alfabeta.

Supartha, I Made, dkk. 2009. Sejarah Kebudayaan Indonesia Religi dan Filsafah. Jakarta:Rajawali Pers.
Tanudjirjo, Daud Aris Dkk. 2004. Merajut Persada Puasaka Budaya Melayu Jambi. Jambi: Kementerian Kebudayaan dan Pariwisata.

Usman, Husaini. 2014. Metodologi Penelitian Sosial. Jakarta:PT Bumi Aksara.

Utomo, Bambang Budi. 2011. Kebudayaan Zaman Klasik Indonesia di Batang Hari. Jambi: Dinas Kebudayaan dan Pariwisata.

Wirjomartono, Bagoes, dkk. 2009. Sejarah Kebudayaan Indonesia. Jakarta: PT Raja Grafindo Persada. 
